Article

\title{
Terrestrial Species in Protected Areas and Community-Managed Lands in Arunachal Pradesh, Northeast India
}

\author{
Nandini Velho ${ }^{1, *}$, Rachakonda Sreekar ${ }^{2}$ and William F. Laurance ${ }^{1}$ \\ 1 Centre for Tropical Environmental and Sustainability Science (TESS) and College of Marine and \\ Environmental Sciences, James Cook University, Cairns, QLD 4878, Australia; bill.laurance@jcu.edu.au \\ 2 School of Biological Sciences, University of Adelaide, Adelaide, SA 5000, Australia; \\ rachakonda.sreekar@outlook.com \\ * Correspondence: nandinivelho@gmail.com
}

Academic Editors: Jeffrey Sayer and Chris Margules

Received: 19 August 2016; Accepted: 20 October 2016; Published: 26 October 2016

\begin{abstract}
Protected areas (including areas that are nominally fully protected and those managed for multiple uses) encompass about a quarter of the total tropical forest estate. Despite growing interest in the relative value of community-managed lands and protected areas, knowledge about the biodiversity value that each sustains remains scarce in the biodiversity-rich tropics. We investigated the species occurrence of a suite of mammal and pheasant species across four protected areas and nearby community-managed lands in a biodiversity hotspot in northeast India. Over 2.5 years we walked 98 transects (half of which were resampled on a second occasion) across the four paired sites. In addition, we interviewed 84 key informants to understand their perceptions of species trends in these two management regimes. We found that protected areas had higher overall species richness and were important for species that were apparently declining in occurrence. On a site-specific basis, community-managed lands had species richness and occurrences comparable to those of a protected area, and in one case their relative abundances of mammals were higher. Interviewees indicated declines in the abundances of larger-bodied species in community-managed lands. Their observations agreed with our field surveys for certain key, large-bodied species, such as gaur and sambar, which generally occurred less in community-managed lands. Hence, the degree to which protected areas and community-managed lands protect wildlife species depends upon the species in question, with larger-bodied species usually faring better within protected areas.
\end{abstract}

Keywords: Arunachal Pradesh; community-managed lands; gaur; India; management; parks; patrolling; sambar; tigers

\section{Introduction}

Terrestrial protected areas cover $15.4 \%$ of the world's land area [1]. Within the tropics about a quarter of all forested lands are afforded some degree of protection [2], but the type and extent of protection varies geographically. While land afforded at least some protection is much higher in South and Central America (25\%-28\% of the land is listed in IUCN Categories I-VI, which includes all types of formal protected areas), the figure is much lower in Asia (12.4\%) [1]. Notably, the area of land intended to receive strict protection in the tropics is uniformly low in both the Neotropics and Indo-Malayan region [3].

The diversity of land-protection regimes in the tropics provides a setting in which to understand the relative importance of protected areas compared to adjacent forests that are often managed by resident communities. Furthermore, the relatively small fraction of strictly protected areas can often make their ecological representation, species populations, and biodiversity patterns inadequate 
within the entire protected-area network $[4,5]$. However, protected areas are important reservoirs for maintaining biodiversity [6] and reducing deforestation [7]. They are often considered the first line of defence for wildlife protection [8] and have important values for biodiversity and community well-being [9].

Continuing anthropogenic pressures arising from habitat loss, fragmentation, and hunting are serious challenges in protected areas [10-12]. As protected areas continue to be degraded and adjacent community-managed lands are converted for agriculture and other human uses, obtaining on-ground information about the relative biodiversity values of protected areas and community-managed lands remains a crucial challenge. Past evaluations have largely focused on forest cover $[7,13]$ and abiotic pressures such as fire frequency [2] as proxies for reserve "health", but often these comparisons are geographically unmatched-limiting one's confidence in their conclusions. However, researchers are recognizing that comparisons should be matched $[2,14,15]$, with a focus on expanding metrics to understand the responses of animal species [14]. At the same time, the evidence supporting the efficacy of community-forest management remains weak because of a paucity of rigorously designed studies [16].

An understanding of protected areas versus community-managed lands is especially important in a highly populous, megadiverse developing country such as India. This nation sustains half of the world's tigers, 60 percent of all Asiatic elephants, and 70 percent of all one-horned rhinoceros [17,18]. Although the threats to biodiversity vary widely by species and region, habitat loss and degradation and hunting remain the predominant stresses to Indian biodiversity $[6,19]$.

Arunachal Pradesh, in northeast India, harbours two global biodiversity hotspots, and has the second-highest level of biodiversity globally, after the northern Andes [20]. The decline in important mammal species such as tigers are impacted by socioeconomic changes and institutional inadequacies [19,21]. Our study seeks to addresses how much biodiversity (defined as a range of detectable mammals and pheasants) is harboured in formally protected areas versus adjacent community-managed lands.

Specifically, we used transect-based animal-sign surveys in conjunction with interviews with local residents to assess the persistence of a range of mammal species in each management regime across four independent sites, using a paired study design. We predicted that (a) occurrence of larger-bodied species would be higher in protected areas and (b) key-informant observations will reflect species occurrences in each of these two management regimes relatively accurately.

\section{Study Area}

Our study area spanned four independent, paired sites (eight sites in total, Figure 1) in the Kameng Protected Area Complex, which, at $3500 \mathrm{~km}^{2}$, is the largest contiguous forest tract in the Eastern Himalaya Global Biodiversity Hotspot. Historically, there has been no formal land-tenure system in the state, apart from the established hierarchy of ownership rights among tribes: individual, family, clan, village, and tribe. Different tribes and clans have clearly demarcated land management and inter-community land boundaries that operate as areas of management. The relatively recent Arunachal Pradesh (Land Settlement and Records) Act, 2000 and Scheduled Tribes and Other Traditional Forest Dwellers (Recognition of Forest Rights) Act, 2006 tried to formalise land-tenure for individuals, but customary rights are still exercised by different tribes. In the past, although parcels of land may have been privately owned in community-managed lands, there was no formalized system of issuing certificates; ownership was and is still based on an understanding between individuals of the same tribe. However, issuing Land Possession Certificates for private ownership requires inspection and clearance from multiple levels, including the Forest Department, Village Council heads, and the District Administration. Therefore, in the same community-managed lands, there may be unofficial land tenure systems that are based on established mutual and inter-personal agreements and official systems that are based on government records. In this region, protected areas are owned and managed by the state government (they are supposed to restrict encroachment, logging, hunting, 
and other anthropogenic activities, as mandated by the Wild Life (Protection) Act, 1972), whereas in community forests (or Unclassified State Forests) tribal people exercise their customary rights, that include collecting fuel wood and non-timber forest products. Thus community-managed lands also had more variable land-use patterns. Furthermore, while the Wild Life (Protection) Act, 1972 prohibits hunting of listed species, often cultural and village-level restrictions on hunting vary in the degree of overlap with this legislation.

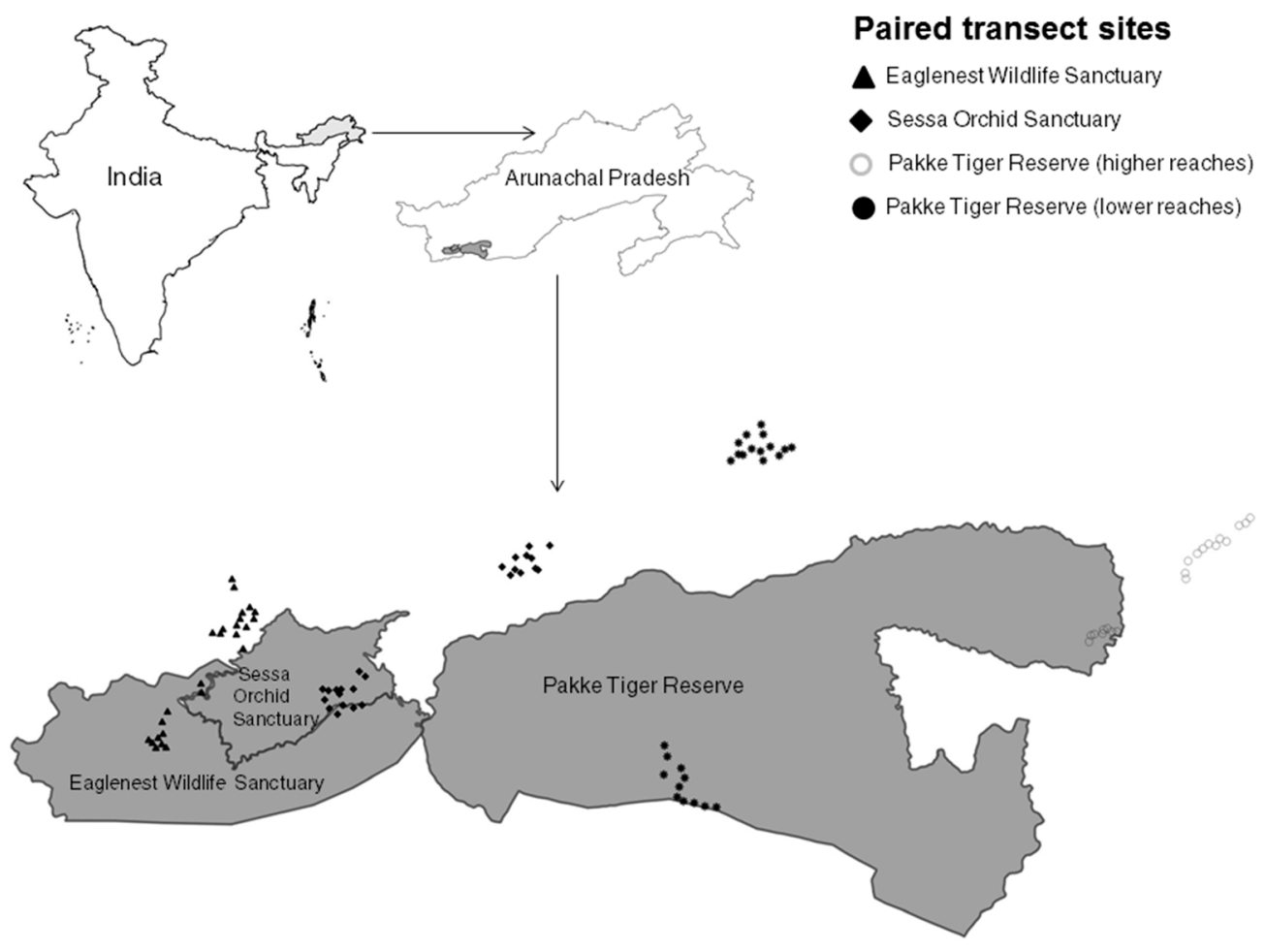

Figure 1. Map of the study area, showing transect locations in the four protected areas (grey) and community-managed lands (white).

We sampled community-managed lands belonging to four tribes, Nyishi, Aka, Bugun, and Shertukpen, between August 2011 and April 2014. Our study spans three protected areas and the adjacent community-managed lands of these four tribes. Thus, we have four independent comparisons of respective community-managed lands: at the lower (median: $667 \mathrm{~m}$ a.s.l.) and higher (median: $1346 \mathrm{~m}$ a.s.l.) reaches of Pakke Tiger Reserve, at Sessa Orchid Sanctuary, and at Eaglenest Wildlife Sanctuary.

Topographically, the paired sites are similar. The aspect (median: 210.4, 95\% CI: 24.6-351), elevation (1155, 95\% CI: 142-2785.4) and slope (19.7, 95\% CI: 1.6-36) in community-managed lands is similar to that in the protected areas (aspect: 186.8, 95\% CI: 18-335.2, elevation: $1417.5,95 \%$ CI: 141-2481.6 and slope: $23.2,95 \%$ CI: 0.7-44.7).

\section{Data Collection}

\subsection{Sign Surveys}

Each of these four sites has a road or a path that we used as a sampling backbone. Within each site, we used several $1 \mathrm{~km}$ long segments of the path or road as independent units to sample different habitat types: agriculture and fallow; secondary and logged forests; and primary forests (which we define as relatively undisturbed forests with no ongoing anthropogenic modification). For each 1-km segment of road, we walked $500 \mathrm{~m}$ long U-shaped transects within the habitat of interest. At each 
transect, we recorded direct and indirect signs of detectable terrestrial mammals and larger birds, such as pheasants, every $20 \mathrm{~m}$. Two observers walked along each segment a few metres apart, recording these signs independently. In total, we had 44 transects in protected areas and 54 transects in community-managed lands; the sample size for the latter was slightly larger given that they had more varied land-use types than did the protected areas. From October 2011 to March 2013, we walked a total of 98 transects, of which we re-sampled roughly half of these transects (48) at two sites (Eaglenest Wildlife Sanctuary and the lower reaches of Pakke Tiger Reserve).

\subsection{Interviews}

Given that we were interested in understanding local views towards species abundance trends, we asked respondents to classify species on a scale from -2 (for extirpations) to +2 (for large increases), with a score of zero indicating no change in abundance. We were also interested in comparing the perceptions of perceived abundance trends over time in a community-managed land and protected area. For this comparison, the key informant profiles in the community-managed lands were the same as those mentioned above and mainly belonged to the Aka tribe, with a lower number from the Nyishi tribe. The lower reaches of Pakke Tiger Reserve are uninhabited and so we chose to interview long-term research assistants, people involved in nature-based tourism, forest watchers, and guards. As such, their profiles differ from the typical interviewees at other sites. We acknowledge that population declines might be underestimated within Pakke (because many of the interviewees worked for the Forest Department and might not be comfortable reporting declines), but we hope to have minimised this bias as one of the authors (Nandini Velho) has worked with and become well known to the key informants at Pakke over the past eight years. In this way, we conducted a total of 84 key informant interviews (46 within the protected area and 38 from the community-managed lands) from our paired site in and around Pakke Tiger Reserve.

\section{Statistical Analysis}

We used Program R (R Development Core Team 2015) for all analyses. In all areas, except within the Eaglenest Wildlife Sanctuary (where domestic hunting dogs and the semi-domesticated cattle-like mythun or mithun Bos frontalis were not present), we excluded certain animals from the species-level analysis because it is difficult to distinguish their signs. Specifically, signs of domestic dogs and wild dogs are very similar, as are the signs of the mythun and its wild counterpart, the gaur (Bos gaurus). Therefore, these species were excluded from the analyses.

For our analysis of species richness for selected mammals and birds, we used the average number of signs per transect (averaged across two repeats, where applicable) in a transect-by-species matrix. We used the package vegan to calculate species richness and perform site-wise comparisons. We report bootstrapped values of species richness and standard errors to make site-wise comparisons among the four sites. The estimated species richness was similar whether we used only fresh signs or all signs, and hence we used the latter for our analysis. Additionally, we constructed rank-abundance plots and fitted log-normal models of species abundance (for community-managed lands and protected areas) for each of the four sites using the "radfit" function in the package vegan [22]. Higher evenness in the community is represented by shallower estimates (close to zero) of the species abundance distribution. To determine whether protected areas had greater evenness (shallower estimates) than community-managed lands, we followed Gelman \& Hill [23]. We used the "sim" function in the arm package to construct $95 \%$ confidence intervals of our parameter estimates by resampling 1000 times from its posterior distribution. An approximate one-tailed $p$-value of two samples was estimated as follows: $p=1-(\mathrm{x} / \mathrm{n})$, here " $\mathrm{x}$ " is the number of samples where estimates of the protected area was greater than the 50th quantile (median) estimate of the community-managed land, and " $\mathrm{n}$ " is the total number of resamples [24].

To investigate the relationship between species occurrence and body mass in protected areas and community-managed lands, we used our transect data to get the proportion of segments where 
each species was encountered. The body mass data for most species was drawn from [25]. We used generalised linear models (GLMs) with binomial error structure to model the effects of body mass on occurrence probability for each site. We used McFadden's pseudo- $R^{2}$ to calculate the deviance explained by the GLMs. We then used the method recommended by [23] (see above for details) to determine if the model estimates of protected areas are greater than community-managed lands.

Our interview analysis only included species for which there were at least 10 responses by key informants. If our interviewee was unsure about species identity (or thought it was not found in the area), the species was excluded as a data point from that interview. Using this approach, we had enough information to model population trends of 23 species from within Pakke Tiger Reserve and 29 species from within the adjacent community-managed lands. We used general linear models (GLMs) to determine the effect of body mass on average species scores, as larger animals are often selectively hunted. Again, we used the method recommended by Gelman and Hill [23] to determine if the model estimates for protected forests are greater than for community-managed forests. We used an average body size for similar-looking otter species, two macaque species, and six pheasant species.

\section{Results}

\subsection{Species Richness}

In general, protected areas had slightly higher species richness (range of estimated species richness bootstrap: 13-17) than community-managed lands (10-15) (Figure 2). The lower reaches of Pakke Tiger Reserve and Sessa Orchid Sanctuary had higher species richness compared with the community-managed lands, whereas Pakke's higher reaches and Eaglenest had almost similar richness between regimes (Figure 2). Similarly, the species evenness was higher in protected areas than community-managed lands of Pakke's lower reaches $(p<0.001)$ and Sessa $(p<0.001)$, whereas Pakke's higher reaches $(p=0.46)$ and Eaglenest $(p=1)$ had similar evenness (see Figure 3$)$. The community-managed lands of Eaglenest appeared to have higher richness and evenness (Figures 2 and 3). Barking deer, porcupines, small carnivores, and pheasants were frequently encountered on transects in community-managed lands. Elephant, sambar, gaur, and barking deer were frequently encountered in protected area sites, except for Sessa Orchid Sanctuary (Figure 3).

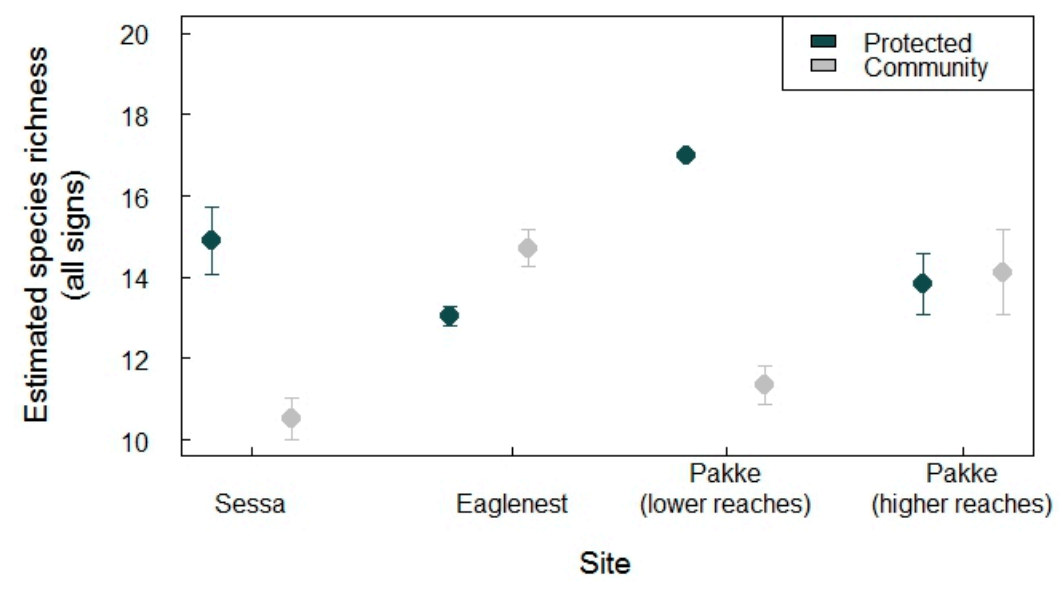

Figure 2. Bootstrapped species richness estimates with standard errors across four independent site comparisons. Pakke Tiger Reserve (lower reaches) had the highest species richness, while the community-managed land adjacent to Sessa had the lowest. 

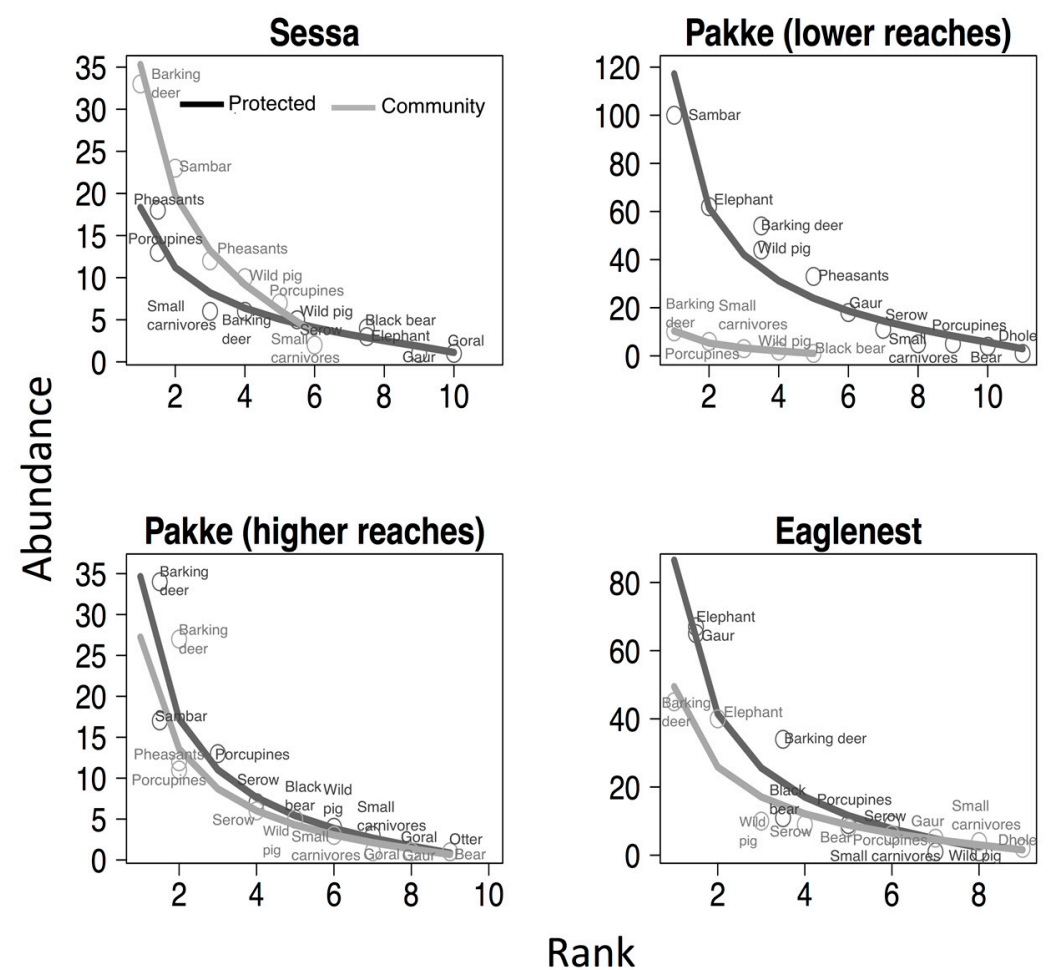

Figure 3. Plots showing species evenness in protected areas and community-managed lands. Species rank abundance distribution plots are fitted with lognormal models. Lines and points are trends and species occurrences in protected areas (dark grey) and community-managed lands (light grey). Protected areas of Sessa and Pakke's lower reaches had higher evenness than their community-managed lands.

\subsection{Occurrence}

In protected areas, the occurrence probability of terrestrial mammals increased with body mass in the lower reaches of Pakke Tiger Reserve (GLM: $\left.R^{2}=0.05, p=0.018\right)$ and Eaglenest Wildlife Sanctuary $\left(R^{2}=0.11, p<0.001\right)$. The higher reaches of Pakke Tiger Reserve $\left(R^{2}=0.04, p=0.124\right)$ did not show any relationship with body mass and Sessa was the only protected area where occurrence of terrestrial mammals decreased with increasing body mass $\left(R^{2}=0.25, p<0.001\right.$; Figure 4$)$. In contrast, across three of the four community-managed lands the occurrence probability of terrestrial mammals decreased with increasing body mass (Sessa: $R^{2}=0.05, p=0.048$; Pakke lower reaches: $R^{2}=0.20, p=0.002$; Pakke higher reaches: $\left.R^{2}=0.28, p<0.001\right)$. The community-managed lands around Eaglenest were the only exception, where there was no observable relation with body mass $\left(R^{2}=0.02, p=0.16\right.$; Figure 4$)$. The model estimates were higher in protected areas than community-managed lands in all locations (Pakke LR: $p<0.001$; Pakke HR: $p=0.006$; Eaglenest: $p=0.013$; Figure 4), except for Sessa $(p=0.92$ ). This indicates that larger species had steeper declines in community-managed lands at all locations except Sessa. 

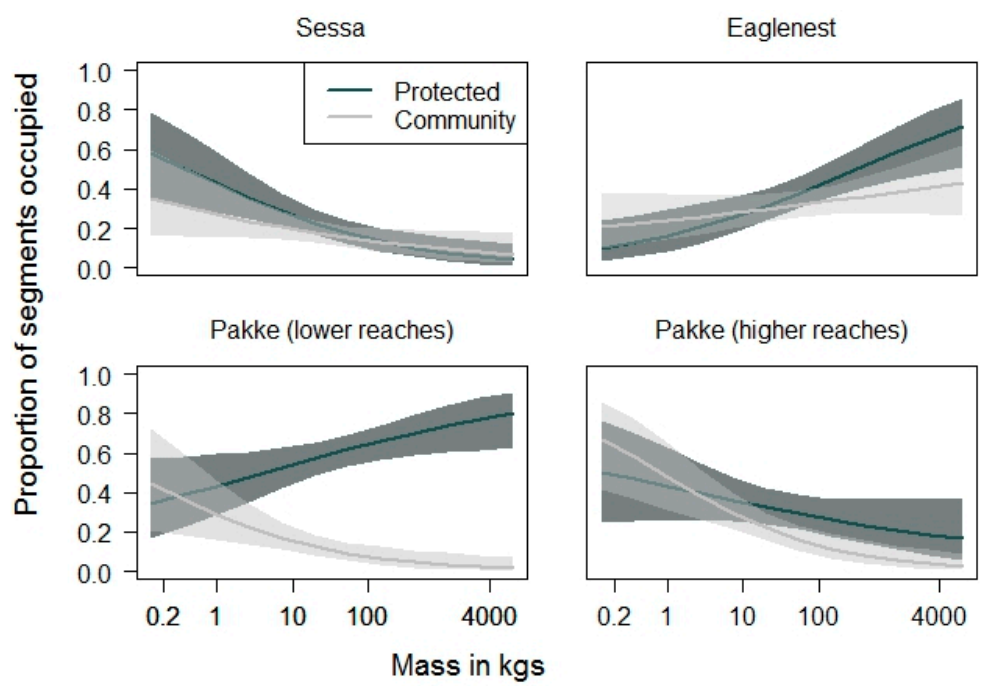

Figure 4. Probability of occurrence of terrestrial vertebrates as a function of body mass. Lines represent model predictions and the shaded dark and light grey regions $95 \%$ confidence intervals. The occurrence probability of large-bodied species declined more steeply in community-managed lands than in protected areas, at all locations except Sessa. Note that the $\mathrm{x}$-axis is on a log scale.

\subsection{Interviews}

When the mean interview scores of species (i.e., the perceived abundance over the last 30 years) were modelled against body size, the estimated $(p<0.001)$ values of Pakke Tiger Reserve were greater than for community-managed lands, indicating a decline in species abundance with body mass in community-managed lands (Figure 5). Interviewees perceived relatively stable abundances of sambar, gaur, elephant, and tiger in the sites around Pakke Tiger Reserve, and associated perceived decreases of these species with adjacent community managed-lands (Figure 5). Qualitatively similar trends were found from our transect data as well (Figure 6).

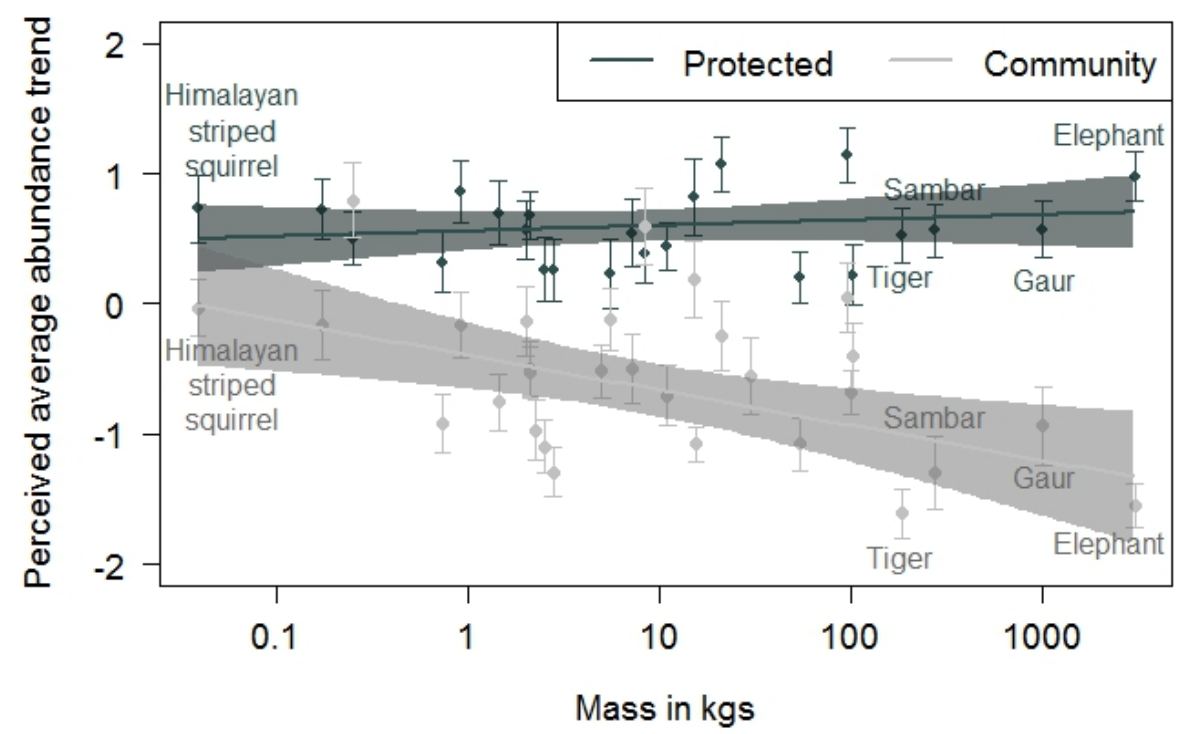

Figure 5. Average scores for perceived species trends based on key informant interviews. The black dots are means and standard errors for each species in Pakke Tiger Reserve, whereas the grey dots are means and standard errors for each species in the adjacent community-managed lands. The solid lines show the fitted ordinary least-squared prediction for species as a function of increasing body mass, and the shaded polygons are the $95 \%$ confidence interval. Note that the $x$-axis is on a log scale. Community-managed lands showed a negative perceived abundance trend with increasing body mass. 

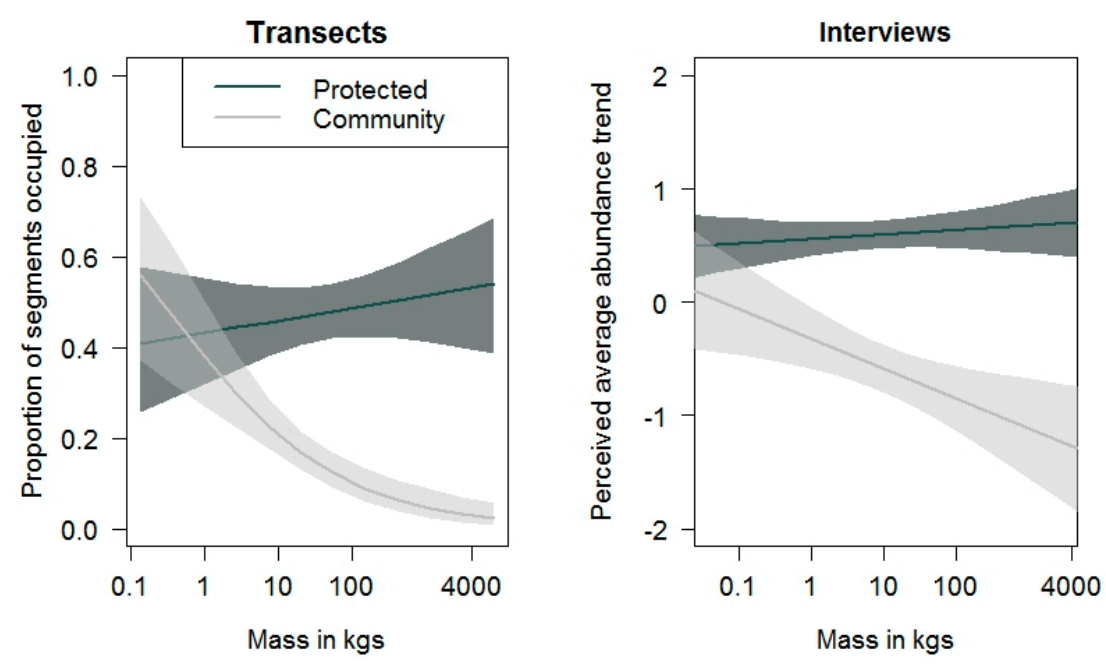

Figure 6. Graphical comparisons of transect and interview data from Pakke Tiger Reserve showing similar patterns of species abundance with body mass. Solid lines and their shaded polygons represent model fits and $95 \%$ CIs, respectively. The $\mathrm{x}$-axis is on a log scale.

\section{Discussion}

Our study shows that protected areas are important for large vertebrates. In general, larger-bodied mammal species had higher occurrences in protected areas than in community forests (Figure 4). We also show that well-managed community lands can be as important as protected areas. For example, vertebrates in community-managed lands and protected areas of Eaglenest and the higher reaches of Pakke had similar richness, evenness, and probability of occurrence (see Figures 2-4).

Key informants report a decline in larger-bodied species in community-managed lands, but not in protected areas (see Figure 5). We acknowledge the limitations of this comparison as the respondents in each area have differing profiles. However, our interviewees' observations of a less steep decline in larger-bodied species in Pakke Tiger Reserve are supported by our field data (Figure 6). Others have also found local knowledge to be a useful tool for biodiversity monitoring [26], though we caution that such data might be difficult to use for elusive and morphologically confusing species. Taken together, our field and interview data indicate that protected areas are important for large-bodied herbivores such as sambar and gaur, and for top predators such as the tiger. These large-bodied species, our interviewees perceived, had declined in abundance in community-managed lands (see Figure 5). Other studies have also noted the relative importance of protected areas for large-bodied species such as elephants [14] and other mammalian and bird species [27,28].

Given that there are multiple reserves within the Kameng Protected Area Complex, future studies should focus on longer-term estimation of key faunal species to identify if and where there are source populations. A positive outcome for people and wildlife may be a mosaic landscape of protected areas in a matrix of community-managed lands. If so, an understanding of dispersal constraints and functional connectivity [29] within the landscape might allow one to better predict the potential of protected areas and community-managed lands to regain some of their extirpated species. Furthermore, there are nuances related to politics, economics, and other social aspects that need to be factored in when considering the strengthening of protected-area networks [30]. This is especially needed as protected areas are considered to be least effective in Asia when compared with other regions [12]. Nonetheless, we find that anti-poaching efforts in the lower reaches of Pakke Tiger Reserve (which also has high anthropogenic pressures) are likely to have benefits for hunted mammals and birds. Faunal species richness and occurrence, moreover, are much lower in surrounding community-managed land than in the reserve itself. At the other end of the spectrum is Sessa Orchid Sanctuary, which has a highway passing through it; here forests are rapidly being converted to other land-uses because of illegal logging and agricultural expansion. 
Depending on the context, the matrices of community-managed lands around protected areas hold promise and potential for wildlife conservation. For example, species richness in the higher-altitude community-managed lands of Eaglenest are comparable to the protected area (see Figures 2 and 3). These community-managed lands may have low hunting pressures compared with other sites, most likely because of the prevalence of both Buddhism and nature-based tourism. Although species richness was low in the community-managed land around Sessa Orchid Sanctuary, it still had higher occurrences of species compared with the adjacent protected area, indicating that there might be some pockets outside reserves where species are still found in high abundances. The community-managed lands around Sessa Orchid Sanctuary have low population pressures as many local people have moved to smaller towns that are more centrally located. Thus land-use, land cover, and management activities at each of the paired sites are likely to be an important driver of biodiversity persistence, and merit further investigation.

To our knowledge, our study is one of the first to examine the differences in biodiversity values of protected areas and community-managed lands at multiple paired sites in the tropics. The possibility of finding community-managed lands that harbour significant biodiversity values should be explored further, as such lands and management could complement existing protected areas and may well function better than open-access areas [31,32]. The State Government, through draft legislation (Arunachal Forest Act, 2014), seeks to regulate human extractive use of these community forests (Unclassified State Forests). More importantly, it plans to formulate rules for land-use management, moving to a more centralised governance structure. The reclassification of land should not solely focus on creating more formal and smaller reserves but should also recognise the importance of community-managed lands in the larger landscape as a whole. There are other opportunities to improve governance and land-use planning in many of these community-managed lands so that biodiversity outcomes could be bettered. For example, it would be helpful to incentivize Village Council leaders to work with the Forest Department to help implement regulations related to the hunting of large-bodied species on community-managed lands. In Arunachal Pradesh, $62 \%$ of the forests are such community-managed lands [33]. At the same time, active management in protected areas is likely to be beneficial, especially in areas that have high anthropogenic pressures. Even in the absence of active management, protected areas still retain important biodiversity values on a large scale.

Acknowledgments: We thank Dinesh Subbha, Bharat Tamang, Shambu Rai, Chamu Rai, Mangal Rai, Gorey Rana, Elizabeth Soumya, Meghna Agarwala, Aditi Kulkarni, Dumbar Pradhan, Bhayung Marphew, Lobsang Marphew, Koliya Sarmah, Maran Degio, Miyali Sidisow, Gentlhe Yamhe, Madhu Degio, Panneerselvam Karthikeyan, Bikram Aditya Roy, Priya Singh, Soren Goyari, Radhe Nabam, Nana Nabam, Ranjan Mallick and Chandan Ri for their assistance in the field. Our special thanks to Luis Velho, Nima Tsering Monpa and Putul Sarmah for support and advice, and to Ramana Athreya and Neelam Dutta for useful inputs. Arunachal Forest Department provided permits. Millo Tasser supported our work in Eaglenest and Tana Tapi supported our work in Pakke and other places. Our gratitude to Indi Glow and the Singchung Village Council for their support and enthusiasm while working in the community forests around Eaglenest. Immense help was extended by Pema Mosobi, Nana Khrimey, the Tukpen Village Council, and the Degio clan of Bana. Susan Laurance and Umesh Srinivasan helped refine ideas and supported us throughout this study. We thank Jeffrey Sayers, Matthew Linkie, and Marc Hockings for their comments on this manuscript. The Rufford Foundation partially supported Nandini Velho through a small grant. William F. Laurance thanks the Australian Research Council for funding.

Author Contributions: Conceived and designed the study: N.V. and W.F.L. Data collection: N.V. and W.F.L. Analyzed the data: R.S. and N.V. Wrote the paper: N.V., R.S. and W.F.L.

Conflicts of Interest: The authors declare no conflict of interest.

\section{References}

1. Juffe-Bignoli, D.; Burgess, N.; Bingham, H.; Belle, E.; de Lima, M.; Deguignet, M.; Bertzky, B.; Milam, A.; Martinez-Lopez, J.; Lewis, E.; et al. Protected Planet. Report 2014. Tracking Progress towards Global Targets for Protected Areas; United Nations Environment Programme World Conservation Monitoring Centre: Cambridge, UK, 2014. 
2. Nelson, A.; Chomitz, K.M. Effectiveness of strict vs. multiple use protected areas in reducing tropical forest fires: A global analysis using matching methods. PLoS ONE 2011, 6, e22722. [CrossRef] [PubMed]

3. Jenkins, C.N.; Joppa, L. Expansion of the global terrestrial protected area system. Biol. Conserv. 2009, 142, 2166-2174. [CrossRef]

4. Rodrigues, A.S.; Andelman, S.J.; Bakarr, M.I.; Boitani, L.; Brooks, T.M.; Cowling, R.M.; Fishpool, L.D.C.; da Fonseca, G.A.B.; Gaston, K.J.; Hoffmann, M.; et al. Effectiveness of the global protected area network in representing species diversity. Nature 2004, 428, 640-643. [CrossRef] [PubMed]

5. Venter, O.; Fuller, R.A.; Segan, D.B.; Carwardine, J.; Brooks, T.; Butchart, S.H.; Marco, M.D.; Iwamura, T.; Joseph, L.; O'Grady, D.; et al. Targeting global protected area expansion for imperilled biodiversity. PLoS Biol. 2014, 12, e1001891. [CrossRef] [PubMed]

6. Karanth, K.K.; Nichols, J.D.; Karanth, K.U.; Hines, J.E.; Christensen, N.L. The shrinking ark: Patterns of large mammal extinctions in India. Proc. R. Soc. Lond. B. Biol. Sci. 2010, 277, 1971-1979. [CrossRef] [PubMed]

7. Nolte, C.; Agrawal, A.; Silvius, K.M.; Soares-Filho, B.S. Governance regime and location influence avoided deforestation success of protected areas in the Brazilian Amazon. Proc. Natl. Acad. Sci. USA 2013, 110, 4956-4961. [CrossRef] [PubMed]

8. Bruner, A.G.; Gullison, R.E.; Rice, R.E.; Da Fonseca, G.A.B. Effectiveness of parks in protecting tropical biodiversity. Science 2001, 291, 125-127. [CrossRef] [PubMed]

9. Leverington, F.; Costa, K.L.; Pavese, H.; Lisle, A.; Hockings, M. A global analysis of protected area management effectiveness. Environ. Manag. 2010, 46, 685-698. [CrossRef] [PubMed]

10. DeFries, R.; Hansen, A.; Newton, A.C.; Hansen, M.C. Increasing isolation of protected areas in tropical forests over the past twenty years. Ecol. Appl. 2005, 15, 19-26. [CrossRef]

11. Laurance, W.F.; Useche, D.W.; Rendeiro, J.; Kalka, M.; Bradshaw, C.J.A.; Sloan, S.P.; Campbell, M.; Abernethy, K.; Alvarez, P.; Arroyo-Rodriguez, V.; et al. Averting biodiversity collapse in tropical forest protected areas. Nature 2012, 489, 290-294. [CrossRef] [PubMed]

12. Spracklen, B.D.; Kalamandeen, M.; Galbraith, D.; Gloor, E.; Spracklen, D.V. A global analysis of deforestation in moist tropical forest protected areas. PLoS ONE 2015, 10, e0143886. [CrossRef] [PubMed]

13. Ellis, E.A.; Porter-Bolland, L. Is community-based forest management more effective than protected areas?: A comparison of land use/land cover change in two neighbouring study areas of the Central Yucatan Peninsula, Mexico. For. Ecol. Manag. 2008, 256, 1971-1983. [CrossRef]

14. Goswami, V.R.; Sridhara, S.; Medhi, K.; Williams, C.A.; Chellam, R.; Nichols, J.D.; Oli, M.K. Community-managed forests and wildlife-friendly agriculture play a subsidiary but not substitutive role to protected areas for the endangered Asian elephant. Biol. Conserv. 2014, 177, 74-81. [CrossRef]

15. Carranza, T.; Balmford, A.; Kapos, V.; Manica, A. Protected area effectiveness in reducing conversion in a rapidly vanishing ecosystem: The Brazilian Cerrado. Conserv. Lett. 2014, 7, 216-223. [CrossRef]

16. Bowler, D.E.; Buyung-Ali, L.M.; Healey, J.R.; Jones, J.P.G.; Knight, T.M.; Pullin, A.S. Does community forest management provide global environmental benefits and improve local welfare? Front. Ecol. Environ. 2011, 10, 29-36. [CrossRef]

17. Madhusudan, M.D. Living with large wildlife: Livestock and crop depredation by large mammals in the interior villages of Bhadra Tiger Reserve, South India. Environ. Manag. 2003, 31, 466-475. [CrossRef] [PubMed]

18. Amin, R.; Thomas, K.; Emslie, R.H.; Foose, T.J.; Strien, N.V. An overview of the conservation status of and threats to rhinoceros species in the wild. Int. Zoo Yearb. 2006, 40, 96-117. [CrossRef]

19. Datta, A.; Anand, M.O.; Naniwadekar, R. Empty forests: Large carnivore and prey abundance in Namdapha National Park, north-east India. Biol. Conserv. 2008, 141, 1429-1435. [CrossRef]

20. Price, T. Eaglenest Wildlife Sanctuary: Pressures on biodiversity. Am. Nat. 2012, 180, 535-545. [CrossRef] [PubMed]

21. Aiyadurai, A.; Singh, N.; Milner-Gulland, E.J. Wildlife hunting by indigenous tribes: A case study from Arunachal Pradesh, North-East India. Oryx 2010, 44, 564-572. [CrossRef]

22. Oksanen, J.; Blanchet, F.G.; Kindt, R.; Legendre, P.; Minchin, P.R.; O’Hara, R.B.; Simpson, G.L.; Solymos, P.; Stevens, M.H.H.; Wagner, H. Vegan: Community Ecology Package. Available online: https:/ CRAN.Rproject.org/package=vegan (accessed on 24 July 2016).

23. Gelman, A.; Hill, J. Data Analysis Using Regression and Multilevel/Hierarchical Models; Cambridge University Press: New York, NY, USA, 2007. 
24. Sreekar, R.; Huang, G.; Zhao, J.; Pasion, B.O.; Yasuda, M.; Zhang, K.; Peabotuwage, I.; Wang, X.; Quan, R.; Slik, J.W.F.; et al. The use of species-area relationships to partition the effects of hunting and deforestation in a fragmented landscape. Divers. Distrib. 2015, 21, 441-450. [CrossRef]

25. Menon, V. A Field Guide to Indian Mammals; Dorling Kindersley: New Delhi, India, 2003.

26. Anadon, J.; Gimenez, A.; Ballestar, R.; Perez, I. Evaluation of local ecological knowledge as a method for collecting extensive data on animal abundance. Conserv. Biol. 2009, 23, 617-625. [CrossRef] [PubMed]

27. Reddy, G.V.; Karanth, U.K.; Kumar, N.S.; Krishnaswamy, J.; Karanth, K.K. Recovering Biodiversity in Indian Forests; Springer: Singapore, 2016.

28. Velho, N.; Srinivasan, U.; Singh, P.; Laurance, W.F. Large mammal use of protected and community-managed lands in a biodiversity hotspot. Anim. Conserv. 2016, 19, 199-208. [CrossRef]

29. Vasudev, D.; Fletcher, R.J.; Goswami, V.R.; Krishnadas, M. From dispersal constraints to landscape connectivity: Lessons from species distribution modeling. Ecography 2015, 38, 967-978. [CrossRef]

30. Symes, W.S.; Rao, M.; Mascia, M.B.; Carrasco, L.R. Why do we lose protected areas? Factors influencing protected area downgrading, downsizing and degazettement in the tropics and subtropics. Glob. Chang. Biol. 2016, 22, 656-665. [CrossRef] [PubMed]

31. Shahabuddin, G.; Rao, M. Do community-conserved areas effectively conserve biological diversity? Global insights and the Indian context. Biol. Conserv. 2010, 143, 2926-2936. [CrossRef]

32. Rao, M.; Nagendra, H.; Shahabuddin, G.; Carrasco, L.R. Chapter 10. Integrating community-managed areas into protected area systems: The promise of synergies and the reality of trade-offs. In Protected Areas: Are They Safeguarding Biodiversity? Wiley Blackwell: Hoboken, NJ, USA, 2016; pp. 169-192.

33. Menon, S.; Pontius, R.G.; Rose, J.; Khan, M.L.; Bawa, K.S. Identifying conservation-priority areas in the tropics: A land-use change modelling approach. Conserv. Biol. 2001, 15, 501-512. [CrossRef]

(C) 2016 by the authors; licensee MDPI, Basel, Switzerland. This article is an open access article distributed under the terms and conditions of the Creative Commons Attribution (CC-BY) license (http://creativecommons.org/licenses/by/4.0/). 